\title{
Relationship between several meteorological factors and phenological features of pear cultivars
}

\author{
Lakatos, L. ${ }^{1}$, Szabó, T. ${ }^{2}$, Kocsisné, M.G. ${ }^{3}$, Racskó, J. ${ }^{4}$, Soltész, M. ${ }^{5}$, Szabó, Z. ${ }^{1}$ \& Nyéki, J. ${ }^{1}$ \\ ${ }^{1}$ University of Debrecen, Centre of Agricultural Sciences and Engineering, Faculty of Agricultural and Food \\ Sciences and Environmental Management, H-4032 Debrecen, Böszörményi str. 138. \\ ${ }^{2}$ Research and Extension Centre for Fruit Growing, H-4244 Újfehértó, Vadastag 2. \\ ${ }^{3}$ University of Pannonia Georgikon Faculty of Agriculture, H-8360 Keszthely, Deák F. str. 16. \\ ${ }^{4}$ Ohio Agricultural Research and Developmnet Center, OH 44691-4096 (USA) 1680 Madison Avenue \\ ${ }^{5}$ Collage of Kecskemét, Faculty of Horticulture, H-6000 Erdei Ferenc tér 1-3.
}

\begin{abstract}
Summary: The aim of this paper was to investigate the flowering characteristic of apples and their relationship to meteorological parameters. The trees observed are grown at Újfehértó, Eastern Hungary in the plantation of an assortment (gene bank) with 586 apple varieties. Each of the varieties were observed as for their dates of subsequent phenophases, the beginning of bloom, main bloom and the end of bloom over a period between 1984 and 2001 during this period the meteorological data-base keeps the following variables: daily means of temperature $\left({ }^{\circ} \mathrm{C}\right)$, daily maximum temperature $\left({ }^{\circ} \mathrm{C}\right)$, daily minimum temperature $\left({ }^{\circ} \mathrm{C}\right)$, daily precipitation sums $(\mathrm{mm})$, daily sums of sunny hours, daily means of the differences between the day-time and night-time temperatures $\left({ }^{\circ} \mathrm{C}\right)$, average differences between temperatures of successive daily means $\left({ }^{\circ} \mathrm{C}\right)$. Between the $90^{\text {th }}$ and $147^{\text {th }}$ day of the year over the 18 years of observation. The early blooming varieties start blooming at 10-21April. The varieties of intermediate bloom start at the interval 20 April to 3 May, whereas the late blooming group start at 2-10 May. Among the meteorological variables of the former autumnal and hibernal periods, the hibernal maxima were the most active factor influencing the start of bloom in the subsequent spring.
\end{abstract}

Key words: bloom time, ripening time, meterological factor

\section{Introduction}

\section{Survey of the purpose and importance of monitoring plant phenological processes and its literature}

Growth and development of plants is fundamentally coded in their inherited genetic constitution, but manifestation of the expression of the particular genes depends on the complex effects of a defined environment. The environment is subject within wide limits to periodically repeated changes, especially through returning seasons of the successive years, moreover, the geographic conditions of a given site are though decisive as far as the main characters of the seasons, the variable combination of the environmental components, temperature, humidity, light intensity and atmospheric movements may cause various stresses and adversities with hardly predictable frequencies. In addition to happening determined mainly by the local climate, other components of the site are changing the fate of living organisms, as the soil and other biotic and abiotic factors, especially the agroor phytotechnical interventions of man, which may modify substantially even the original climatic conditions e.g. by watering and nutrition.

It is almost a common-sense that the rate of growth development is largely under the influence of the climate and the weather conditions. The seasonal life cycle of, plants are divided into distinct phases recognized easily by their appearance (phenophases), which are closely related mainly with temperature, consequently, the regular monitoring of phenophases associated with the changes of temperature reveal the regularities called phenology, a characteristic of plant species (Bacsó, 1966) moreover, variability of individual genotypes within the same species. The beginning of a new phenophase is recognized by the appearance of a new organ (e.g. flower) or loss of petals of leaves. The life of a plant during the whole year is divided into distinct phenophases, which are not obligately coincident with developmental phases not always recognized by naked eye.

The life cycle of plants belonging to different species or within one species to varieties manifest their genetically coded character also by their different specific phonological performance recognized and described under the same conditions. Whereas the weather of another year with different environmental conditions (e.g. temperatures) may change the phenology of the compared varieties by a different wax. The rhythm, speed and intensity of phenophases characteristic to the varieties of a species may be changed by manipulating the genotype, i.e. by the methods of plant breeding. The subsequent phenophases of related varieties may coincide, overlap each other or move away (Brózik \& Nyéki, 1974). 
Bubán (1998) defined growth as the realisation of genetic program on the charge of an input of energy by the modifying contribution of correlated factors of environment, which activate the manifestation of a series of genes according to a genetically fixed order, therefore the organization of biological functions are changing continuously.

Phenological observations are strictly bound to the calendar, but for the purpose of comparing years, sites and meteorological data, the rigid scale of the calendar is suppressed and weather cycles or arbitrary units are used (five-day period, week, decade or month). Terms of phonological periods are given the preference as thoughtful orientations, which hall-mark the actual weather data. The characterization of e.g. thermal demand of the respective phonological phenomena is derived from those observations. Similarly, de water supply of apple trees could not be approached with terms fixed in the calendar, because the incidents of precipitation as the rhythm of warming up during the spring time used to be extremely variable, but the information of three weeks before apple bloom is significant.

The length of phenophases is determined first of all by the meteorological elements: temperature, precipitation, and radiation. Temperature and rainfall used to have optimal values, which may vary according to varieties, however, those values are not stable because of the interactions with other meteorological factors and e.g. with the respective soil conditions, etc. (Lakatos, 1997). With increasing temperatures the length of phenophases tends to shorten, whereas precipitation being coupled with a with a drop of temperature, may prolong the periods. An excessive shortening of phenophases - especially of the fruit growing process - may diminish yield and impairs fruit quality.

In exploring relations between phenophases and meteorological phenomena, the basic concept climatology should kept in mind, the climate is always a complex of many interacting factors. E.g. low temperature may reduce water demand of plants, high temperature on the contrary increases it.

High importance ought to be given to phenology in timing of phytosanitary operations. This refers to the cultivated plant as well as to the predator or to the pathogen. Most elaborate technologies are strictly bound to special phenophases of the host plant, many diseases of fruit trees, e.g. monilia of stone fruits or apple scab (Holb, 2002) have to be sprayed to exactly defined phenophases as a condition of full efficiency.

Information derived from phonological observations is needed to optimize the effects of man power and of a disposable machine pool. The exact phonological monitoring is also useful in predicting future expectations.

\section{The effect of meteorological elements on the life rhythm of fruit trees}

The effect of individual elements may not be observed immediately on the trees of the plantation, because the microclimate of the site may change the dynamics and length of the phenophases and productivity (Berényi, 1958). Among the meteorological factors, the radiation is most susceptible to become dominant under the canopy of the trees, because a modified penetration of sunshine is decisive to the timely and spatial distribution of other elements as temperature, airhumidity, etc.

The microclimate of plantations depends beyond the meteorological regime also on a couple of factors, which are bound to the growing site as well as to biological and phytotechnical moments. (Szász \& Tökei, 1997). The spatial order of the trees, the distance and orientation between and within the rows, the form and dimension of the crown. Those are the components of the ecological environment, which determine the adaptability of a given genotype (Kárpáti, 1960).

The life processes of fruit trees are undisturbed within set limits of temperature only. All deviations from the optimum is both direction are deleterious to productivity as well as to fruit quality. temperature is satisfactory to growth and development within relatively narrow limits only. According to the law of van't Hoff, increasing temperature accelerates the speed of chemical reactions by a rate of two fold per an increase of $10{ }^{\circ} \mathrm{C}$. However, the validity of this law is restricted to a narrow interval only regarding the phonological processes. (Szász \& Tökei,1997).

Most of weather adversities in Hungarian fruit growing are due to the temperature minima during the winter and spring, whereas heath may become deleterious as well (Szabó, 1997). The efficiency of photosynthesis is diminished above $\left(30-35^{\circ} \mathrm{C}\right)$ because dissimilative processes become dominant.

The initiation of a new phenophase occurs certainly on the biochemical level, and becomes visible after some delay first on the microscopic level only. Therefore, the phenophases are sometimes difficult to be distinguished by morphological criteria (Racskó, 2001), as a matter of fact the phenophases remain latent. At the time of bud development all buds seem to be leaf buds. The initiation of flower primordial ensues in different fruit species and varieties at a set time during the summer. Its first visible sign is the change of form in the growing meristem tip of the bud. The development of primordial of flowers and/or inflorescences is a slow process during the eng of summer, autumn (paradormancy) and the first part of winter but keeps to be continuous (Brózik \& Nyéki, 1975). This phenophase is called ectodormancy, which changes to the next phase and the spring. The latter one is very susceptible to temperature changes, as the warming up accelerates the formation of flowers up to bud burst and blooming (Bubán, 2003).

The effect of temperature on the development of buds has been studied by Szabó (1997), and he stated that during the period of endodormancy, buds and aerial, lignified parts of fruit trees are practically hot damaged by low temperatures or $-20{ }^{\circ} \mathrm{C}$ (below zero) in Hungary. As endodormancy finished, any temperature above zero ${ }^{\circ} \mathrm{C}$ stimulates the life processes of the trees (Holdefleiss, 1930) and abolishes gradually that frost resistance experienced during endodormancy. The regression of frost resistance in the flower buds and flowers continues until the end of bloom and fruit set, which is the 
most frost susceptible period of the fruit trees (Soltész, 1997). Even $-0,5{ }^{\circ} \mathrm{C}$ may prove to be deleterious to the developing ovules (seed primordial). Low temperatures along blooming, especially coupled with precipitation cause stress in plants and renders the flowers susceptible to infection of Monilinia on stone fruits. The relation of phenophases and meteorological phenomena - especially temperature - was most explored around the bloom of fruit trees. The blooming process has been analyzed meticulously by Nyéki (1980, $1981,1990,2002$ ) and divided into the following sub-periods 1. Start of bloom (1-5\% of flowers opened on the tree), 2. Main bloom (the ratio of open flowers is $50 \%$ or more), 3 . The day of main bloom The ratio of open florets achieved a maximum), 4. End of bloom (when $95-100 \%$ of flowers shed their petals).

It is the easiest to determine the start of bloom, therefore it is considered to be the most characteristic for the respective genotype of the tree and for distinguish varieties. In the literature, there are difficulties with the comparison of data because the authors applied different criteria as for the definition of phenophases.

The length of endodormancy (a phenophase) of apple varieties is determined by the demand of a set number of chilling hours, i.e. until that demand is not fulfilled, the rising temperature does not trigger the process of flower development. Mild winters may cause reversion of the customary blooming order of varieties in the following spring because endodormancy of some varieties still did not finish (Nyéki et al., 2004). In case if in all varieties the endodormancy expired regularly (normal or rather long winters), the blooming order will not be disturbed (Soltész, 1992)

An important moment of the blooming process is the dynamic of blooming (Orosz-Kovács, 2002). The number of open flowers on the first day, on the first three days and on the main blooming day may comprehensively characterize the "dynamic" of bloom (Nyéki, 1980). Knowing the data of the first three days, the whole blooming process could be estimated. Out of the three dates, the effect of the variety dominates in the first and gradually diminishes conceding to the effect of the season. Temperatures above $10^{\circ} \mathrm{C}$ registered one or two dasx before the start of bloom is very closely correlated with the rate of flowers opened at the first dax $(\mathrm{r}=\mathrm{m} .78)$.

Excessively high temperatures during bloom shorten the length of blooming period, pollen is quickly released but the drying out of the stigmatic fluid lowers the probability of pollen grains being caught and fertilization ensued. The chance of the flowers being visited by pollinating bees declines at the same time (Brózik \& Nyéki, 1975). Summing up, the chance of flowers being pollinated and ovules being fertilized is low with high temperatures during bloom (Szabó, 1997).

The relief of the growing site also influences the manifestation of meteorological factors, i.e. the development of plants indirectly (Bacsó, 1946). Trees grown on a slope of NE exposition are slower in displaying the sequence of phenophases than those of southern exposition (Mohácsy, 1946).

Unfavourable climatic conditions and their deleterious effect could be counteracted more or less by a series of phytotechnological measures. E.g. the chances of frost damage threatening the flower buds and later flowers during the phase of ectodormancy are diminished by slowing down the development of the buds. During March and April, the dely of bloom may become as long as 10 days caused by watering the soil or the aerial parts of the trees (Szabó, 1997).

After bloom, the fertilised flowers set fruit and the growth of fruitlets starts immediately. The growth of the fruits is also divided to sub-periods, which are varietal properties also subject to meteorological influence (Szalay, 2003).

Ripening, as the last phase of fruit development is associated with changes of quality meaning complicated biomechanical process (Okályi, 1954). Harvest of the fruits ought to be performed earlier than the complete biological maturity of the fruit and its exact date is referred to as technological maturity (Szász, 1988). The exact distinction of the phenophase as for the technological maturity of individual varieties is hardly approached all over by plain phonological means. The phenological signs of maturity are specific for most varieties (e.g. changes of the ground colour and/or covering colour of the fruit skin, the force needed to pick the fruit, the firmness of the fruit flesh, accumulating of sugar, regression of acidity, etc)(Brózik \& Nyéki, 1974).

Unusually hot weather accelerates ripening, the fruits may stay smaller and of lower quality, less attractive by aspect.

\section{Materials and methods}

The beginning of bloom is, as explained above, a genetically coded character although subject to environmental influence, i.e. the weather of the season.

The trees observed are grown at Újfehértó in the plantation of an assortment (gene bank) of apple varieties of the Society of Public Utility for Fruit Growing and Extension Service.

Each of the 586 varieties is represented by two trees, which have observed as for their dates of subsequent phenophases, the start of bloom, the main bloom and the end of bloom over a period between 1984 and 2001 .

For the analysis of data the varieties have been grouped according to dates of maturity, blooming period as well as types of the seasons.

Groups of maturity dates:

- summer ripe,

- autumnal ripening,

- winter ripe varieties.

According to the dates of blooming:

- early blooming,

- intermediate blooming,

- ate blooming varieties.

The different seasons according to the weather of the spring: 
- rainy

- dry

- sunny

- cloudy, overcast

- cool

- warm

According to the length of fruiting period (Date of maturity)

- short

- medium

- long

The classification of the seasons has been performed by statistical means. Precipitation, number of sunny hours and mean temperature are considered during the whole blooming period. The variation has been calculated around the respective sums (precipitation, sunny hours) or means (temperature). That was the way to establish the six categories.

\section{The methods of research}

- We analyzed the time series' fluctuation by the dispersion D

- Determined the different weather characteristics with the mentioned equation

For examnle:

- Rainy $f(x) \geq \bar{x}+D$

- Dry $f(x) \leq \bar{x}-D$

Where ' $D$ ' is the dispersion of time series and ' $\bar{x}$ ' is the pattern's average

With this similar method we can classify

- Sunny

- Cloudy, overcast

- Cool

- Warm years

- For the researching plant-weather relationship we use a simple, well known statistical methods

- Correlation and regression analysis

Applied procedure

- We used the SPSS 11.0 software for the linear regression fitting and for calculation of dispersions as well.

- The tables made by Excel programme.

\section{Meteorological variables examined}

The developmental cycles, as the physiological processes of the trees, are influenced not only by the actual weather but also by the meteorological happening of the past years. The former year, is also considered in the exploration of causes manifested in varying blooming dates, especially the start of bloom.

Between 1983 and 2001 the meteorological data-base keeps the following variables:

- daily means of temperature $\left({ }^{\circ} \mathrm{C}\right)$

- daily maximum temperature $\left({ }^{\circ} \mathrm{C}\right)$
- daily minimum temperature $\left({ }^{\circ} \mathrm{C}\right)$

- daily precipitation sums ( $\mathrm{mm}$ )

- daily sums of sunny hours

- daily means of the differences between the day-time and night-time temperatures $\left({ }^{\circ} \mathrm{C}\right)$

- average differences between temperatures of successive daily means $\left({ }^{\circ} \mathrm{C}\right)$

Those variables served to calculate means of the respective growing seasons, which in turn are the base of computing correlation and regression coefficients characterizing the start of blooming of apple varieties.

\section{Results}

Approximately the half of the varieties examined (46\%) start blooming between the $114^{\text {th }}$ and $121^{\text {st }}$ day, i.e. between April 24 an May 17 and before March 31, blooming occurs very rarely.

Within the interval of 1984-2001 over 18 years, the earliest bloom started in 1990 April 3, and the latest in 1997 May 1.

The highest frequency of starting bloom is expected between April 26 an May 3.

\section{The frequency of starting bloom in varieties of different blooming time}

As the data of examined varieties of different blooming dates over 18 years have been evaluated we may draw the following consequences:

The early blooming varieties start blooming at April 10-12. The varieties of intermediate bloom start at the interval April 20-May 3, whereas the late blooming group start at May 2-10. The curve of distribution in the case of early blooming varieties is skewed to the right. It means that the probability of starting bloom increases with the time elapsed. The group of intermediate blooming time shows the distribution most approaching normality, but there are regressions along this course. That anomaly is attributed to the inconstancy of spring weather. The distribution curve of start of bloom in late blooming varieties is a zigzag line. The steep peeks are characteristic. The amplitude of the distribution is the narrowest in this group.

\section{The distribution of starting bloom according to different types of years}

The distribution of starting bloom in rainy and dry type of years. In Figurel the function curves prove that bloom started earlier by 4-5 days in dry years than in rainy ones. However, the dynamic of flowering was slower in dry years by 1-2 days.

The number sunny hours influenced decisively the dynamic of bloom. The results show clearly the favourable effect of sunshine in stimulating the start of bloom by 7-8 days compared with the cloudy years (Figure 2). The amplitude of variation in the start was much less remarkable, as it was 1-2 days shorter in sunny days than in cloudy ones. 
The most remarkable differences is the distribution of starting bloom are experienced between the years characterized as warm and cool. In warm years the start of bloom ensued 8-9 days than in cool years, moreover the amplitude of variation was also narrower in warm years by $7-8$ days (Figure 3 ). The cool years produce a quasi-normal function slightly skewed to the left with numerous steep regressions. The cause of it is the unfavourable, chilly weather. In warmer years, on the contrary, the curve is almost regularly normal (Figure 3).

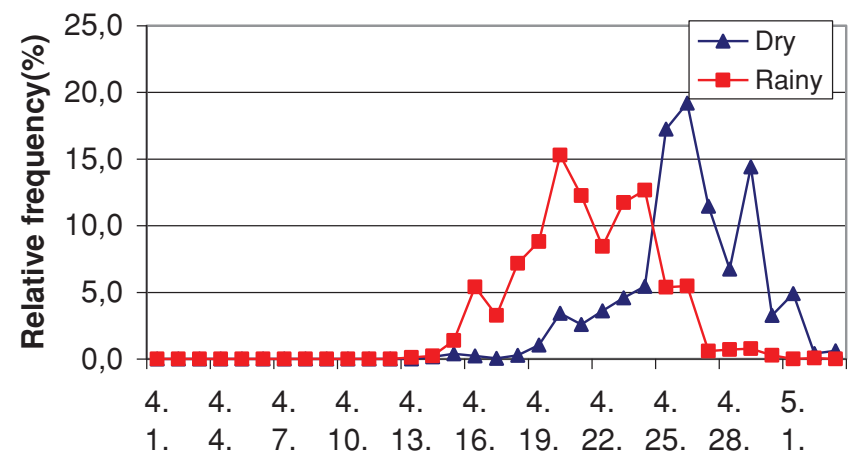

Calendar date of starting bloom

Figure 1. Distribution of the beginning of blooming time in dry and humid years (Újfehértó, 1984-2001)

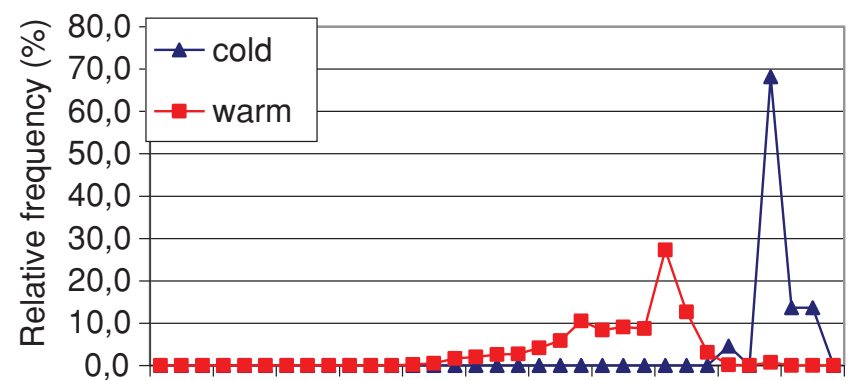

4. 4. 4. 4. 4. 4. 4. 4. 4. 4. 4. 5.

1. 4. 7. 10. 13. 16. 19. 22. 25. 28. 1.

Calendar date of starting bloom

Figure 2. Distribution of the beginning of blooming time in cold and warm years (Újfehértó, 1984-2001)

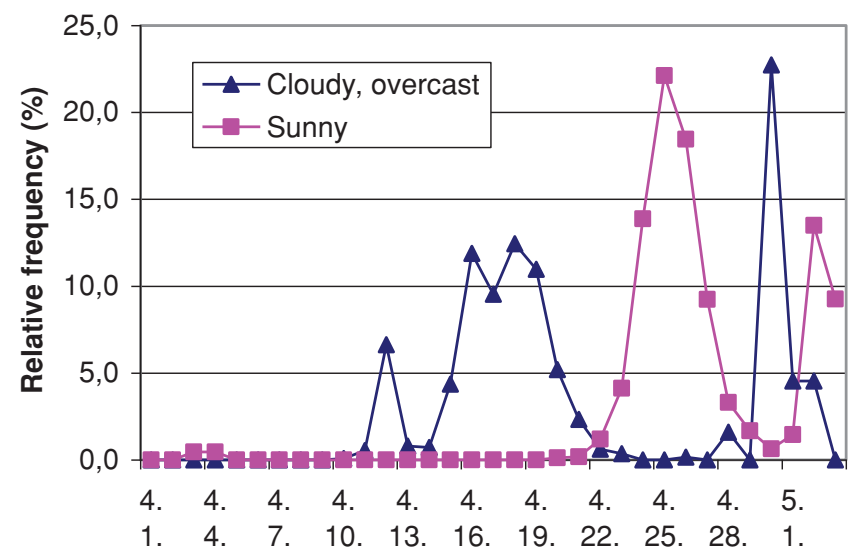

Calendar date of starting bloom

Figure 3. Distribution of the beginning of blooming time in cloudy and sunny years (Újfehértó, 1984-2001)

\section{The relations of the start of bloom and the different components of the meteorological environment}

On the basis of time series of the beginning of bloom we can stated that starting points of flowering are shifted 10 days earlier during the last 18 years period (Figure 4).

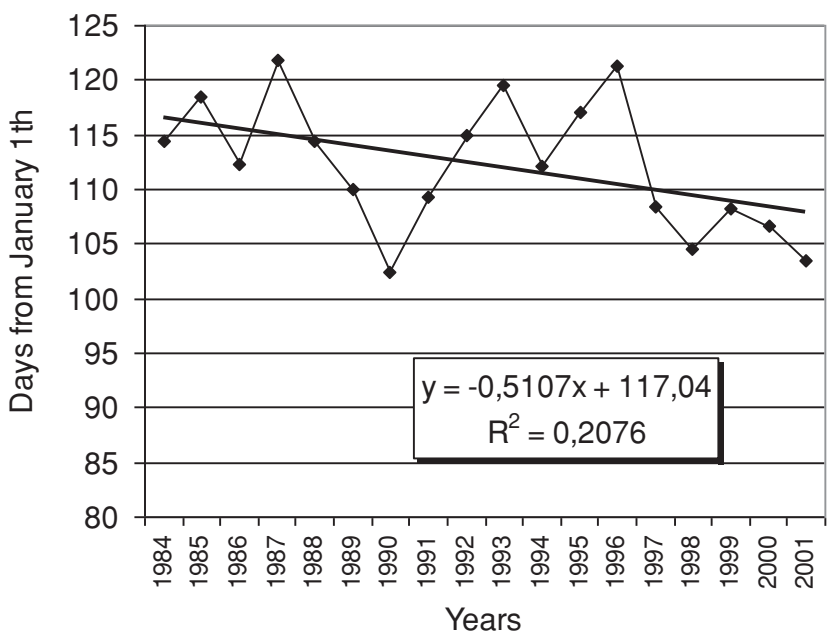

Figure 4. Time series of the beginning of bloom in pear gene bank plantation (Újfehértó, 1984-2001)

Out of the meteorological variables or components the spring temperature maxima, the mean temperature of the spring as well as the difference between the mean daytime and night-time temperatures produced a significant correlation with the start of bloom on the level of $\mathrm{P}=5 \%$. We have also found significant correlation between minimum temperature and beginning of bloom (Figure 5).

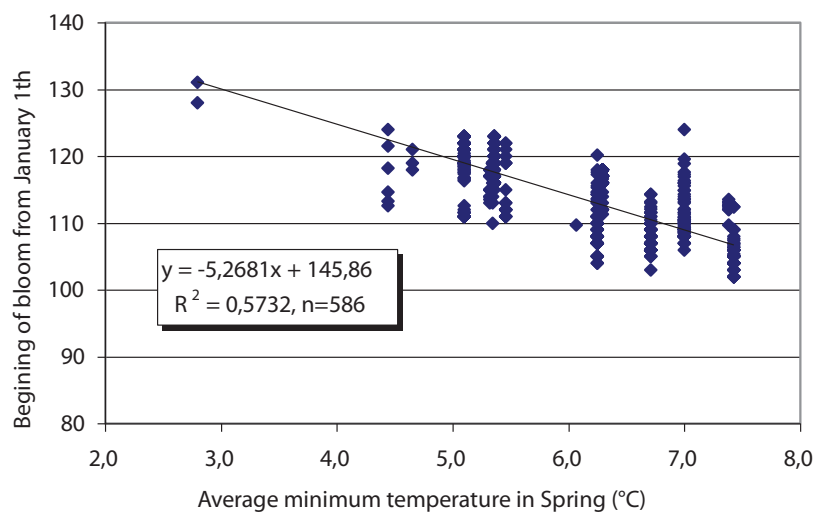

Figure 5. Relationship between the begining of bloom and minimum temperature in Spring time in pear gene bank (Újfehértó, 1984-2001)

If the specific length of the fruiting season of the varieties and the start of bloom are plotted against the meteorological parameters of the past year, the following consequences have been drawn:

If the varieties, which started bloom lately were considered, there was a significant effect attributed to the autumnal precipitation, the mean winter temperature and winter minima, the autumnal and hibernal maxima on the start of bloom, valid at $\mathrm{P}=5 \%$ level. In the variety groups 
of early and intermediate blooming dates, there was no significant effect detected of the meteorological parameters of the former year on blooming data. All the three groups of varieties reflected to the hibernal sunshine with blooming dates, significantly. The varieties of a longer fruiting period manifested the effects of the mean differences between daytime and night-time hibernal temperatures, significantly.

Among the meteorological variables of the former a autumnal and hibernal periods, the hibernal maxima were the most active factor influencing the start of bloom in the subsequent spring.

In the group of early blooming varieties, there was a significant correlation (at $\mathrm{P}=5 \%$ level) between the mean temperature, the minima and maxima of the former spring and the mean temperatures of the summer on the one hand and the start of bloom in the respective spring on the other hand. The start of bloom of varieties of intermediate blooming time reflected significantly the effects of the summer precipitation, the mean differences of daytime and nighttime temperatures and the spring minima. The late blooming varieties did not reflect by their start of bloom the effects of any meteorological parameter measured in the former year. The groups distinguished by different lengths of fruiting period started blooming as being as being susceptible, significantly, to the summer precipitation and to the mean differences between daytime and nighttime summer temperatures of the previous year.

Among the meteorological parameters the mean differences of daytime and nighttime summer temperatures of the last year seemed to be effective on the start of bloom.

There is a significant correlation between average night and day temperature diffrences and length of blooming period (Figure 6).

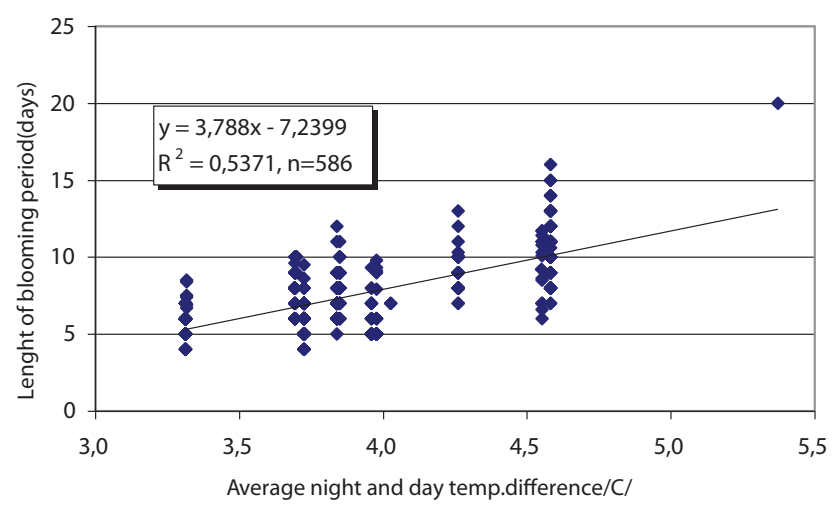

Figure 6. Relationship between the length of blooming and the average night and day temperature diffrence in Spring (Újfehértó, 1984-2001)

The general statements concerning the relation between the spring weather of the current wear and the date of bloom in different groups of varieties, regarding start of bloom and length of fruiting period are the following:

The date of starting bloom is less influenced by the spring weather of the current wear in the early blooming group of varieties. For all the 7 meteorological variables, the influence could not be proved in the date of starting bloom. In the early blooming group of varieties, rather the thermal conditions of spring and summer of the previous wear were decisive. In the intermediate blooming time group of varieties, the spring temperature and the mean differences between daytime and nighttime temperatures proved to be significant in influencing the start of bloom. Similarly, in the late blooming group of varieties, the mean differences between daytime and nighttime was decisive as influencing the start of blooming.

In a mild spring, blooming starts earlier. The larger differences between daytime and nighttime temperatures stimulate the start of blooming. The large amplitude of temperature changes is associated with high daytime maxima during the spring. In the other variety groups too, the two mentioned meteorological variables are decisive in influencing the start of bloom. In addition to that, varieties of intermediate blooming date are significantly influenced by minimum temperatures of the spring. The surprising fact is that is early blooming varieties any of the meteorological variables did not alter significantly the start of bloom. However, weather conditions of the previous year proved to be decisive in determining the blooming dates.

Not only between the blooming date and meteorological parameters we have found significant correlation but between length of vegetation period and minimum temperature of vegetation period (Figure 7).The maturity time important phonological stages for the pear growers, there is also significant relationship between maturity time and minimum temperature from 1 th of January to maturity date (Figure 8).

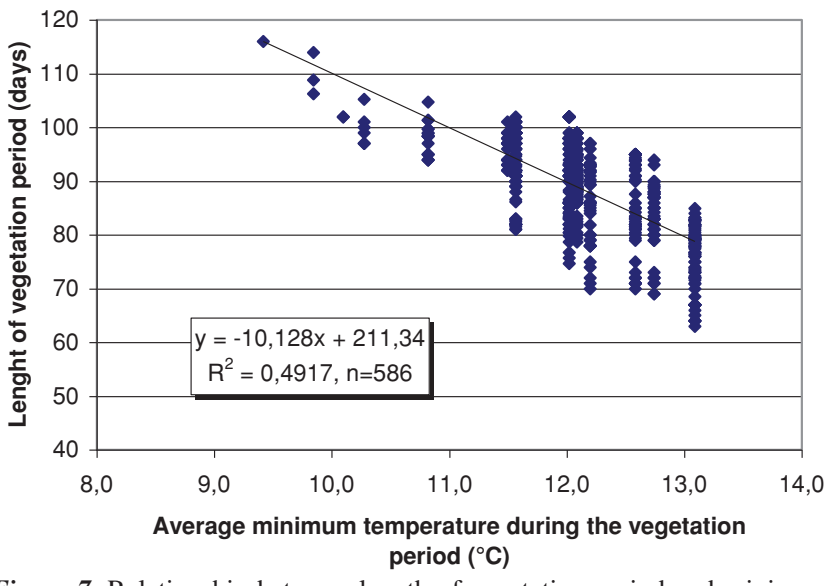

Figure 7. Relationship between length of vegetation period and minimum temperature of vegetation period, (Újfehértó, 1984-2001)

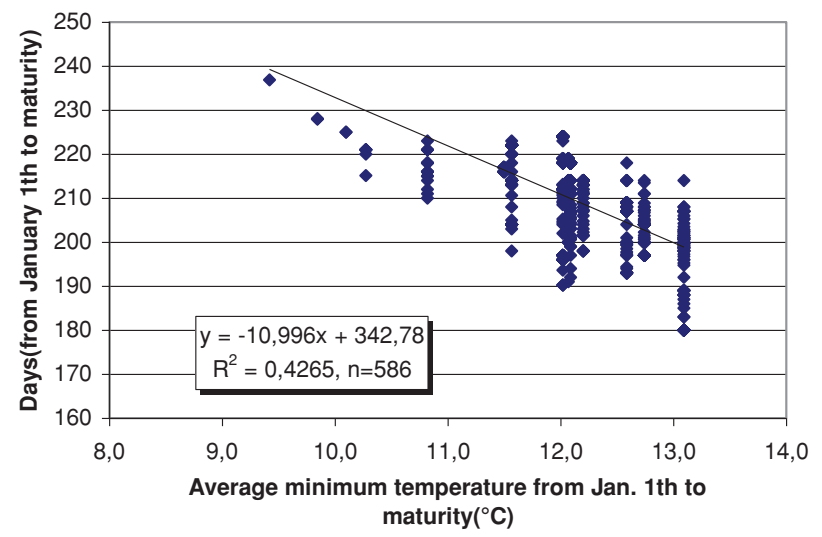

Figure 8 . Relationship between maturity time and minimum temperature from 1th of January to maturity date, (Újfehértó, 1984-2001) 


\section{Conclusions}

- Blooming time shifted to an earlier period by 2 weeks at most of Hungarian fruit cultivation areas

- Positive effects:

- Thanks to the lengthening of vegetation season in the future we can cultivate in the Carpathian basin those plants also which require warmer climate circumstances.

\section{Negative effects of temperature and precipitation changes on plant productioyn}

- Increasing risk of frost occurence later spring, early autumn frost damage ( fruits, vegetables)

- Drought-dryness damage (duration, and occurence growing)

- Extremely high temperature-heatstress (more frequently)

- Huge amount of precipitation during a short period

\section{Acknowledgement}

Research was sponsored by TECH_08-A3/2-2008-0373 and TECH_08-A4/2-2008-0138 grants.

\section{References}

Bacsó, N. (1996): Basic course of Agricultural meteorology (in Hungarian). Mezőgazdasági Kiadó, Budapest. 300. p.

Brózik, S. \& Nyéki, J. (1974): Phenology (in Hungarian). [In: Gyuró, F (szerk.): A gyümölcstermesztés alapjai.] Mezőgazdasági Kiadó, Budapest. 299-318. p.

Brózik, S. \& Nyéki, J. (1975): Fruit set tan pollination (in Hungarian). Mezőgazdasági Kiadó, Budapest. 234. p.

Bubán, T. (1998): Growing parameters of fruits. [In: Soltész, M. (1998): Gyümölcsfajta-ismeret és - használat.] Mezőgazda Kiadó, Budapest. 75-97. p.
Bubán, T. (2003): Developing stages and characteristics of fruits [In. Papp, J. (2003): 1. Gyümölcstermesztési alapismeretek.] Mezögazda Kiadó, Budapest. 127-157. p.

Hann, J. \& Knoch, K. (1932): Handbuch der Klimatologie Stuttgart. 383. p.

Holb, I, (2002): Apple scab biological prediction and protection (In Hungarian). Szaktudás Kiadóház, Budapest. 144. p.

Holdefleiss, P. (1930): Agrometeorologie. Berlin. 234. p.

Kárpáti, Z. (1960): Relationships between geographical circumstances and horticultural production (In Hungarian). MTA Biológiai Osztályának Közleményei. Budapest. 3-4: 219-232.

Lakatos, L. (1997): Climatic model for dry matter production of winter - wheat in Hungary. Agricultural and Forest Meteorology 83, (3/4) 231-246.

Nyéki, J. (1980): Floral biology and fruit set at different fruit varieties (In Hungarian). Mezőgazdasági Kiadó, Budapest. 334.p

Nyéki, J. (1989): Stone fruits flowering and pollination. MTA, Budapest. Doktori értekezés (manuscript) 288+110. p.

Nyéki, J. (1990): Fruit set, pollination, and blooming of fruits Integrated fruit production (In Hungarian). [In: Gyuró, F. Fruit production.] Mezőgazdasági Kiadó, Budapest. 61-90. p.

Okályi, I. (1954): Fruit production (In Hungarian). Egyetemi tankönyv. Budapest 338. p.

Orosz \& Kovács, Zs. (ed.) (2000): Floral biology of apple. Integrated fruit production (In Hungarian). Pécsi Tudományegyetem TTK Növénytani Tanszék és Botanikus Kert - Almatermesztők Szövetsége kiadásában. Újfehértó. 179. p.

Racskó, J. (2001): Biological basis of frost resisitance and possibilities of decreasing harmful effects Integrated fruit production (In Hungarian). Nyír-Gazda. 10:18-19.

Soltész, M. (ed.) (1997): Integrated fruit production (In Hungarian). Mezőgazda Kiadó, Budapest. 843. p.

Szabó, Z. (1997): Decreasing of harmful meteorological effects [In: Soltész, M. (1997): Integrated fruit production (In Hungarian)] Mezőgazda Kiadó, Budapest. 353-359. p.

Szász, G. \& Tőkei, L. (eds.) (1997): Meteorology for agricultural, horticultural experts. Mezőgazda Kiadó, Budapest. 722. p.

Tökei, L. (1997): Effects of temperature on plants. [In: Szász, G. \& Tőkei, L. (eds.): Meteorológia mezőgazdáknak, kertészeknek, erdészeknek.] Mezőgazda Kiadó, Budapest. 390-399. 